\title{
Kiai Ahmad Fauzan: Pemikiran dan Peranannya di Kabupaten Jepara, 1942-1972
}

\author{
M. Dalhar, ${ }^{*}$ Yety Rochwulaningsih, Dhanang Respati Puguh \\ Program Studi S2 Ilmu Sejarah, Fakultas Ilmu Budaya, Universitas Diponegoro
}

*Alamat korespondensi: mbahdalhar7@gmail.com

Diterima/ Received: 11 Juni 2019

Disetujui / Accepted: 4 Juli 2019

\begin{abstract}
This study focuses on the life, ideas, and role of Kiai Ahmad Fauzan in developing Islamic teachings and national values. Islam and nationalism are two things that interconnected and not contradictory. In Indonesian history, the two of them caused turmoil, even opposition. The purpose of this study is to prove the return of the Moslem spirit which is in line with the development of local religious leaders, primarily through case studies of local scholars in Jepara, such as Kiai Ahmad Fauzan. This study used a historical method, including heuristics, source criticism, interpretation, and historiography. Kiai Ahmad Fauzan was a leader of the Nahdlatul Ulama (NU) who fought through education and politics to uphold the Ahlussunah wal Jamaah (Aswaja) ideology in Jepara. Fauzan's Islamic and national ideas can be seen from syair [poems] conveyed to the public. Syair became a media for propaganda for Kiai Ahmad Fauzan in spreading the religious understanding of Islam Aswaja. It is delivered to the community as reminder and awareness of harmonious religious and national values. His role in the religious and socio-political fields was seen when Japan began occupying Jepara in 1942. He was the target of arrest because of his role as a cleric. Its leadership formed from religious roles carried out mainly through madrasa and $d a^{\prime}$ wah by traveling from one village to another. Kiai Ahmad Fauzan was involved in socio-religious organizations such as the Indonesian Islamic Assembly (MIAI), Indonesian Muslim Council (Masyumi), and NU, especially during the 1955 elections. Kiai Ahmad Fauzan was also trusted by the government to be the first leader of the Ministry of Religion in Jepara after independence revolution.
\end{abstract}

Keywords: Kiai Ahmad Fauzan; Ideas; Religious Role; Local Politics.

Abstrak
Kajian ini berfokus pada kehidupan dan pemikiran serta peranan Kiai Ahmad
Fauzan dalam mengembangkan ajaran Islam dan nilai-nilai kebangsaan. Islam
dan nasionalisme adalah dua hal yang saling berhubungan dan tidak
bertentangan. Hal tersebut tampak dalam perjalanan bangsa Indonesia. Akan
tetapi, dalam sejarah perjalanan bangsa Indonesia, antara keduanya saling
menimbulkan gejolak, bahkan pertentangan. Tujuan kajian ini adalah untuk
membuktikan kembalinya semangat Islam yang menjadi mayoritas di Indonesia
dan nasionalisme yang seiring sejalan dengan perkembangan tokoh lokal
keagamaan, khususnya melalui studi kasus ulama lokal di Kabupaten Jepara,
yaitu Kiai Ahmad Fauzan. Metode yang digunakan dalam kajian ini adalah
metode sejarah yang meliputi empat tahap, yaitu heuristik, kritik sumber,
interpretasi, dan historiografi. Kiai Ahmad Fauzan adalah tokoh NU Jepara yang
berjuang melalui jalur pendidikan dan politik untuk menegakkan paham Aswaja
di Jepara. Pemikiran Islam dan kebangsaan Fauzan terlihat dari syair-syair yang
disampaikan kepada masyarakat. Syair menjadi media dakwah bagi Kiai Ahmad
Fauzan dalam menyebarkan paham keagamaan Islam Aswaja. Syair-syair yang
disampaikan kepada masyarakat lebih bersifat pengingat dan penyadaran atas
nilai-nilai keagamaan dan kebangsaan yang selaras. Peranannya di bidang




\begin{abstract}
keagamaan dan sosial-politik terlihat ketika Jepang mulai menduduki Jepara pada 1942. Ia menjadi target penangkapan karena perannya sebagai ulama. Keulamaan dan kepemimpinannya terbentuk dari peran-peran keagamaan yang dilakukan terutama melalui madrasah dan dakwah dengan cara berkelana dari satu desa ke desa yang lain. Kiai Ahmad Fauzan terlibat dalam organisasi sosial-keagamaan seperti Majelis Islam A'la Indonesia (MIAI), Majelis Syuro Muslimin Indonesia (Masyumi), dan NU, terutama saat Pemilu 1955. Kiai Ahmad Fauzan juga dipercaya pemerintah untuk memimpin Kementerian Agama Kabupaten Jepara yang pertama setelah berakhirnya revolusi kemerdekaan Indonesia.
\end{abstract}

Kata Kunci: Kiai Ahmad Fauzan; Pemikiran; Kiprah Keagamaan; Politik Lokal.

\title{
Pendahuluan
}

Adanya fenomena pemberontakan yang terjadi di sebuah negara bukan semata-mata disebabkan oleh faktor keterpurukan ekonomi, ideologi, atau krisis politik. Krisis kebangsaan memegang peranan penting dalam keruntuhan sebuah bangsa dan negara. Di tengah berbagai krisis yang ada di sebuah negara, membangun rasa kebangsaan yang kuat merupakan hal yang sangat penting dilakukan. Atas dasar itu, menjadi penting bahwa berbagai krisis yang ada diselesaikan agar kepercayaan (trust) warga terbangun kepada negara. Krisis kebangsaan diawali dari keraguan untuk hidup bersama sebagai satu negara bangsa yang menjadi alternatif untuk mencapai kemakmuran lahir dan batin (Sianipar, 2002).

Sejarah menunjukkan bahwa Pasca-Proklamasi, terjadi beberapa kali upaya makar yang dilakukan oleh sekelompok orang yang mengatasnamakan agama (Santoso, 2014). Pemberontakan Kartosuwiryo melalui Darul Islam dan Tentara Islam Indonesia (DI-TII) di Jawa Barat menjadi bukti proses berbangsa dan bernegara belum selesai. Masih ada kelompok-kelompok yang ingin mendirikan negara dengan ideologi tertentu di dalam sebuah negara yang sudah merdeka. Sikap tersebut merupakan suatu bentuk resistensi dan separatisme yang dipandang sebagai sikap tidak loyal dan pengingkaran terhadap "konsensus luhur" dari para pendiri bangsa (Sulistiyono, 2015).

Untuk mengatasi krisis kebangsaan yang terjadi, perlu dilakukan upaya bersama dan terintegrasi. Dalam permasalahan tersebut, sejarah memiliki peran strategis untuk membangun kembali rasa kebangsaan sebagai warga negara yang mulai luntur. Sejarah tidak semata memberikan pengetahuan, fakta, dan kronologi, tetapi juga mampu berkontribusi untuk pembangunan, memperkokoh solidaritas bangsa, membangkitkan kebanggaan nasional (national pride), dan menumbuhkan aspirasi terhadap masa depan yang gemilang (Kartodirdjo, 1993).

Kontribusi ulama dalam perjalanan sejarah bangsa Indonesia tidak dapat diabaikan begitu saja. Banyak ulama yang terlahir dari lembaga pendidikan pesantren bersikap nonkooperatif dan turut berjuang mengusir penjajah. Pesantren sebagai ruang kaderisasi ulama tersebar luas di daerah-daerah pedesaan di Jawa, terutama setelah Mataram Islam berdiri di pedalaman Jawa. Sejumlah pesantren berdiri di sekitar keraton, khususnya pascapemerintahan Sultan Agung pada abad ke-17. Salah satu pesantren terkemuka adalah pesantren Tegalsari di bawah asuhan Kiai Hasan Besari di Ponorogo. Pesantren ini berdiri di atas tanah bebas pajak (perdikan) dan diberi 
tugas oleh keraton untuk mendidik para putra raja dan bangsawan (Suryo, 2009). Pesantren juga turut mengatasi kelangkaan dan diskriminasi pendidikan yang ada pada masa pemerintah kolonial Belanda. Pesantren mempunyai akar sejarah yang panjang sekalipun sebagian besar keberadaannya hanya dapat dilacak dari abad ke19 hingga ke-20 (Kuntowijoyo, 1991).

Kehadiran pendidikan Barat pada awal abad ke-20 menjadikan sekolah sebagai pendidikan tunggal sempat menggeser peran strategis pesantren. Kondisi tersebut menjadikan pendidikan Islam masuk dalam isolasi dan malah perlu menyesuaikan diri dengan syarat-syarat pemerintah untuk mendapatkan bantuan dan pengakuan resmi (Steenbrink, 1984). Dikotomi pendidikan yang memisahkan antara ilmu agama dengan ilmu pengetahuan umum tidak menghentikan langkah pesantren sebagai ruang kaderisasi para ulama. Di dalam kurikulum pesantren, ilmu pengetahuan umum dan agama telah terintegrasi (Siradj, 2015). Untuk itu, ketika politik diarahkan pada paradigma Barat, pesantren terus berjalan dengan paradigmanya sendiri. Kemudian lahir banyak tokoh yang bersikap nonkooperatif terhadap pemerintah kolonial, seperti Pangeran Sambernyowo, Pangeran Diponegoro, Paku Buwono VI, K.H. Ahmad Rifai, dan K.H. Hasyim Asy'ari (Florida, 2003, p. 71-75). Dalam sejarahnya, hampir seluruh perlawanan terhadap penjajah dilakukan oleh pimpinan pesantren. Kalau pun dilakukan oleh keraton atau negara, tentu melibatkan para kiai atau ulama dan santri dari pesantren (Siradj, 2015).

Peran ulama terus berlanjut sampai Indonesia merdeka pada 1945. Momentumnya adalah ketika para ulama yang tergabung dalam wadah NU mengeluarkan "Resolusi Jihad" pada 22 Oktober 1945 (Wahid, 1999). Resolusi ini menegaskan sikap para ulama untuk membela kemerdekaan dari upaya kolonialis yang akan merebut kembali kemerdekaan Indonesia. Isinya berupa seruan bahwa jihad fi sabilillah, mempertahankan kemerdekaan dari tangan penjajah, adalah wajib (fardlu 'ain) hukumnya, terutama bagi kaum muslimin yang berada di radius $80 \mathrm{~km}$ dari wilayah pertempuran. Bagi kaum muslimin yang meninggal dalam jihad ini diberi status sebagai syahid.

Fakta tersebut kembali menegaskan bahwa ulama memiliki peranan yang besar bagi negara ini. Peranan ulama yang mengajarkan keteladanan dan nilai-nilai kebangsaan perlu dihadirkan kembali untuk meneguhkan dan menggugah semangat cinta tanah air atau nasionalisme, mengingat pasca-Reformasi 1998, ada banyak kelompok berambisi ingin mendirikan negara Islam (khilafah) di Indonesia. Keberadaan negara dalam negara merupakan sebuah pengingkaran terhadap konstitusi dan kesepakatan final para pendiri bangsa. Hal ini sebagaimana sudah dikukuhkan dalam konstitusi negara yang menyebutkan bahwa bentuk negara yaitu Negara Kesatuan Republik Indonesia (NKRI) tidak dapat diubah, artinya sudah menjadi harga mati (Hady, 2010).

Ulama sebagai bagian dari komponen bangsa ini memiliki kontribusi strategis dalam mempersatukan umat. Otoritas ulama yang bersumber dari syariat agama memfungsikan mereka secara teologis dan sosiologis sebagai penjaga (custodians) dan penafsir hukum Tuhan (Siregar, et al., 2013). Kedalaman ilmu agama yang dimiliki dan 
peranan yang dimainkan di tengah masyarakat menjadikan ulama termasuk dalam kelompok cendekiawan yang berperan sebagai elite kultural dalam masyarakat muslim. Sebagai kelompok kultural dan kelompok nonpolitis, ulama secara strategis menduduki posisi sebagai kelompok mediator yang menjembatani jurang pemisah antara penguasa dan masyarakat (Azra,1989).

Penelusuran terhadap peranan ulama sebagaimana Kiai Ahmad Fauzan merupakan hal yang sangat penting dilakukan mengingat generasi sekarang mulai kehilangan contoh teladan (uswatun hasanah). Di samping itu, penggalian ini juga untuk menemukan bagaimana sebenarnya peranannya di bidang keagamaan dan sosial-politik, karena selama ini kisah-kisah tentang perjuangannya masih berupa kisah tutur (oral history). Harapannya karya ini dapat berkontribusi untuk memperkaya khasanah kebangsaan terutama peranan ulama dalam perjuangan mengisi dan menegakkan kedaulatan NKRI.

Kiai Ahmad Fauzan adalah seorang ulama di Jepara yang berjasa dalam mengisi kemerdekaan baik melalui pikiran, yaitu syair-syair dan peranan di bidang keagamaan dan sosial-politik. Sebagai bentuk apresiasi, namanya diabadikan sebagai nama salah satu jalan di Jepara. Akan tetapi, belum banyak hasil penelitian yang menjelaskan tentang biografi, pemikiran, serta peranan yang dilakukan sepanjang hidupnya. Biografi, pemikiran, dan kontribusinya dalam memberdayakan masyarakat di Jepara masih dapat ditemukan melalui ingatan kolektif masyarakat maupun kesaksian dari keluarga dan para murid Ahmad Fauzan. Sumber-sumber tersebut tentu saja tidak utuh dan semakin lama akan hilang seiring berjalannya waktu.

\section{Metode}

Sebagai bagian dari kajian sejarah, penelitian ini telah melalui empat tahapan dalam metode sejarah yaitu heuristik, kritik, interpretasi sumber, dan historiografi. Terdapat dokumen-dokumen penting yang berhasil ditemukan dan digunakan untuk menganalisis pemikiran Kiai Ahmad Fauzan, salah satunya adalah dokumen arsip milik keluarga berupa catatan silisilah dan transkrip ceramah-ceramah yang disampaikannya. Catatan ini sebagian adalah hasil tulis ulang dari Hj. Lathifah, salah seorang putri Kiai Ahmad Fauzan yang masih melanjutkan perjuangan dakwahnya. Catatan-catatan syair yang ada masih menggunakan bahasa Jawa dan huruf Arab (baca: pegon).

Di samping catatan-catatan syair, digunakan pula sebagai sumber primer adalah "Catatan Riwayat Hidup al-Maghfurlah Kiai Ahmad Fauzan" dalam peringatan haul ke-22 tahun 1994 dan karya (baca: kitab) yang ditulis Kiai Ahmad Fauzan, Allfiyah alGhazali. Dari riwayat hidup tersebut dapat dijadikan sebagai pedoman awal penyusunan profil Kiai Ahmad Fauzan, sedangkan dari karya syair berbahasa Arab tersebut didapatkan sebuah sintesis pemikiran dari beberapa pemikiran lain yang pernah disampaikan. Di dalam karyanya tersebut dijelaskan banyak hal seperti bab tentang keutamaan ilmu, adab, keadilan, dan sikap hati. Di dalam kitab tersebut juga diberikan nasihat (baca: pitutur) tentang nilai-nilai dasar bagi seorang sufi agar tidak terjadi penyimpangan. 
Sumber-sumber primer lainnya yang digunakan adalah arsip-arsip yang tersimpan di Kementerian Agama (Kemenag) Kabupaten Jepara, Kantor Arsip Daerah Kabupaten Jepara, dan Depo Arsip Harian Suara Merdeka tahun 1950-an. Arsip yang tersedia antara lain foto Ahmad Fauzan sewaktu menjadi Pimpinan Kemenag Jepara tahun 1950-an, Kartu Anggota NU, Surat Keterangan Pegawai Kemenag tahun 1950, dan Kartu Partai NU, dan beberapa pemberitaan seputar Pemilu 1955 di Kabupaten Jepara serta dinamika perpolitikan NU di tingkat nasional.

Selain sumber tertulis, wawancara juga dilakukan untuk memperkaya faktafakta sumber dokumen. Wawancara dilakukan dengan putra-putri Ahmad Fauzan dan beberapa orang yang mengetahui tentang peristiwa yang sedang dikaji. Hal ini masih sangat dimungkinkan karena para saksi sejarah masih ada sampai saat ini. Meskipun usia mereka tidak lagi muda - hal ini sangat memengaruhi memori mereka - namun dengan adanya perbandingan dari narasumber yang diwawancara akan menghasilkan sumber yang kredibel. Wawancara ini digunakan untuk melengkapi informasi-informasi yang ada di dalam sumber tertulis atau arsip. Dengan adanya pembanding ini diharapkan informasi yang diperoleh dapat benar-benar valid.

\section{Figur Kiai Ahmad Fauzan: Ulama Lokal yang Nasionalis}

Kontribusi ulama tidak terbatas dalam lingkup politik dan level nasional semata. Terdapat ribuan, bahkan jutaan ulama di berbagai pelosok negeri ini yang belum tercatat dalam sejarah. Padahal, mereka turut berjasa dalam mengajarkan nilai-nilai yang secara substansi tidak mempertentangkan agama dan negara. Mereka menyebarkan paham-paham yang menjadikan negara aman, damai, baldatun thayyibatun warabbun ghafur.

Kiai Ahmad Fauzan (1905-1972) merupakan satu di antara ulama yang memiliki jasa besar dalam pemberdayaan masyarakat. Kiai Ahmad Fauzan, begitu ia sering disebut, merupakan salah seorang ulama kharismatik di Kabupaten Jepara. Ia dilahirkan di sebuah desa kecil di Distrik Mayong pada 1905. Ia adalah putra keempat dari lima bersaudara yang terlahir dari pasangan Haji Abdurrasul dengan $\mathrm{Ny}$. Thohiroh.

Secara garis keturunan, Kiai Ahmad Fauzan memiliki nasab dari Kasunanan Surakarta. Kakeknya, Haji Ahmad Sanwasi merupakan seorang ulama keraton yang meninggalkan istana saat terjadi Perang Diponegoro (1825-1830). Haji Ahmad Sanwasi adalah sahabat dekat Kiai Umar Al-Samarani yang tidak lain adalah ayah dari Kiai Sholeh Darat. Hal tersebut dapat dilihat dari periode perjuangan dakwah dari keduanya dan di tempat yang sama pula, yakni Mayong. Bahkan menurut salah satu sumber, Haji Ahmad Sanwasi adalah menantu dari Kiai Umar Al-Samarani, yaitu menikah dengan Ny. Darojah, kakak dari Kiai Soleh Darat. ${ }^{1}$ Kiai Umar, selain ulama yang cukup terpandang di kawasan pantai utara Jawa, ia juga adalah orang kepercayaan Pangeran Diponegoro. Kiai Umar berserta kawan, kolega, dan santri-

${ }^{1 " S i l s i l a h ~ K e l u a r g a ~ A h m a d ~ S a n w a s i ~ P e n g g u n g ", ~ d i t u l i s ~ d i ~ B a l e k a m b a n g ~ p a d a ~} 29$ Ramadhan 1424 H/ 2003 M oleh Kiai Zaini Dahlan (Sumber tidak diterbitkan). 
santrinya berjuang gigih mempertahankan kehormatan Tanah Air dari jajahan Belanda (Ulum dan Arbi, 2016).

Melalui ayahnya, yaitu Haji Abdurrasul, Fauzan banyak belajar tentang agama dan sosial-kemasyarakatan. Akan tetapi, masa belajar dengan ayahnya tidak lama karena sang ayah wafat saat menunaikan ibadah haji di Tanah Suci. Proses belajar masa berikutnya berlanjut di pesantren². Tercatat beberapa pesantren yang pernah dijadikan sebagai tempat belajarnya, yaitu Pesantren Balekambang, Pesantren Kasingan Rembang, Pesantren Gemiring, dan Pesantren Tayu. Di samping itu, pada 1924 Kiai Ahmad Fauzan juga berkesempatan melanjutkan perjalanan intelektual ke Makkah dan Madinah (haramain) selama kurang lebih dua tahun. Berbagai perjalanan intelektual itu yang di kemudian hari memengaruhi pemikiran Kiai Ahmad Fauzan³.

Ibu Ahmad Fauzan, Ny. Thohiroh adalah salah seorang cucu dari Syekh Muhammad Arif Sendangsari yang merupakan ulama terkemuka yang hidup pada awal abad ke-19, sezaman dengan Pangeran Diponegoro. Nama Sendangsari yang melekat di belakang namanya merupakan nama tempat (baca: dukuh/dusun) perjuangan dakwahnya. Ia adalah seorang ulama dari Hadramaut Yaman dengan marga Adaniy. ${ }^{4}$ Perjuangan dakwah Islam dan sikap antipenjajah dapat dilihat historiografi lokal setempat. ${ }^{5}$

Salah seorang istri Ahmad Fauzan, Ny. Mukarromah, merupakan cucu dari Haji Sulaiman dari Jakenan, Pati. Nama aslinya adalah Raden Ngabehi Brontodiwiryo. Ia juga diyakini sebagai salah seorang ulama Keraton Surakarta yang bersikap nonkooperatif terhadap Belanda sebagaimana Kiai Umar Al-Samarani dan Haji Ahmad Sanwasi. Banyak anak cucu dari Kiai Sulaiman yang menetap di Kabupaten Pati, Jepara, dan sekitarnya untuk meneruskan perjuangan mendakwahkan Islam. ${ }^{6}$

Terjadinya revivalisme Islam abad ke-19 yang terwujud pada pertumbuhan pesantren di pedesaan, pendirian tarekat-tarekat, jumlah orang naik haji yang

${ }^{2}$ Kiai Ahmad Fauzan turut ke Makkah dalam usia belum baligh. Ia diperkirakan berusia sebelas tahun (1916). Ketika pulang, ia sempat terpisah dari rombongan di Singapura. Keterangan dari putra sulung Kiai Ahmad Fauzan, Kiai Zainurrohman. Kini ia tinggal di Purwokerto. Informasi yang sama juga disampaikan oleh Hj. Latifah Fauzan. Wawancara pada 1 Februari 2018.

${ }^{3}$ Catatan "Riwayat Hidup al-Maghfurlah Kiai Ahmad Fauzan" dalam peringatan Haul ke-22 bulan September tahun 1994 (sumber tidak diterbitkan).

${ }^{4}$ Makamnya di Desa Banjaran, Bangsri, Jepara. Silsilahnya Arif bin Hasyim bin Abdul Muhit bin Hasyim bin Syihabuddin bin Semith bin Arif bin Sholih bin Ahmad bin Ali bin Ahmad bin Hamah bin ainuddin bin Abdullah al-Adniy (Yaman). Keterangan ini berasal dari karya Syekh Muhammad Arif yang ditulis pada 8 Januari 1809. Koleksi digitalisasi naskah di Universitas Nahdlatul Ulama (Unisnu) Jepara.

${ }^{5}$ Kiai Muhammad Masduri, "Syair Sejarah Simbah Muhammad Arif", ditulis pada 1987 dengan huruf Arab dan berbahasa Jawa (pegon). Syair ini dibacakan rutin pada peringatan haulnya setiap 10 Muharram (sumber tidak diterbitkan).

"'Silsilah Raden Ngabehi Brontodiwirjo (Mbah Soleman) Desa Jakenan, Pati tahun 1997" (sumber tidak diterbitkan). 
meningkat, memunculkan kepemimpinan para ulama, kiai, dan haji dalam kehidupan beragama. Dalam konteks tradisional, agama Islam terbukti dapat berfungsi sebagai lambang pemersatu dan sekaligus sebagai ideologi politik, sehingga menimbulkan kekuatan politik luar biasa, antara lain seperti yang diwujudkan dalam gerakan sabilillah, perang jihad, dan sebagainya (Kartodirdjo, 1993).

Dari penjelasan di atas patut dicatat bahwa Ahmad Fauzan, selain keturunan dari ulama, baik dari pihak ayah maupun ibu, juga mengalir semangat perjuangan melawan penindasan dan penjajahan. Mereka bukanlah ulama yang berdiam diri atas penjajahan yang ada, melainkan berperan aktif dan berjuang mengusir penjajah. Sikap tersebut - ingkar terhadap kedhaliman - juga yang tampak dalam pribadi Ahmad Fauzan dalam perjalanan hidup selanjutnya.

\section{Peranan Kiai Ahmad Fauzan dalam Pendidikan}

Masa studi mengenai agama yang panjang, ditambah dengan pengabdian kepada umat (khadim al-ummah) setelah nyantri mendorong terbentuknya keulamaan Kiai Ahmad Fauzan. Peranan yang dimainkan tidak terbatas dalam bidang agama, tetapi juga dalam politik pada era 1950-an. Hal ini sudah terlihat sejak ia menyelesaikan pendidikan pesantren di Tayu dengan mendirikan sebuah sekolah di daerah Bangsri pada 1930-an awal. Melalui lembaga pendidikan tersebut, Kiai Ahmad Fauzan semakin memperkuat peranannya sebagai seorang ulama. Banyak masyarakat belajar di sekolah yang dirintisnya. Kelas antara laki-laki dan perempuan dipisah dan diterapkan dengan sistem berjenjang (Wawancara dengan Yahya, 16 Januari 2018).

Di awal pendirian sampai awal 1970-an, tidak ada seragam khusus yang dikenakan para siswa di madrasah. Anak laki-laki mengenakan sarung dan baju serta berpeci, sedangkan anak-anak perempuan mengenakan kebaya dan kerudung. Kelas dibagi menjadi dua waktu. Pagi sampai siang digunakan untuk murid (siswa) lakilaki, sedangkan waktu siang sampai sore kelas untuk murid perempuan.

Pendirian madrasah dengan model kelas atau klasikal pada 1930-an merupakan sesuatu yang baru bagi komunitas muslim di Jepara (Wawancara dengan K.H. Noor Rochman Fauzan, 20 Februari 2018). Model pendidikan kelas memang sudah ada di Jepara pada awal pemberlakuan Politik Etis tahun 1901. Akan tetapi, sekolah-sekolah yang didirikan oleh pemerintah Hindia Belanda tidak menekankan pendidikan agama. Steenbrink membedakan madrasah dan sekolah dengan karakteristik penekanan kurikulumnya. Meskipun mengajarkan ilmu umum sebagaimana sekolah, namun kurikulum di madrasah sangat menonjolkan nilai religiusitas masyarakatnya. Sementara itu, sekolah merupakan lembaga pendidikan umum dengan pelajaran universal dan terpengaruh iklim pencerahan Barat (Streenbrink, 1986).

Rata-rata siswa dalam satu ruang berjumlah 20 sampai 30 siswa. Istilah kelas tidak lazim dipakai, tetapi istilah yang dipakai adalah shifir yang bermakna tingkatan (Wawancara dengan Zaini, 10 April 2018). Begitu pula dengan sebutan "guru" untuk para pengajar juga jarang digunakan. Istilah yang digunakan adalah "kang" atau "mas" untuk yang masih muda, dan ustadz bagi yang lebih tua. 
Pembentukan sebuah lembaga pendidikan tidak menghentikan gerak langkah Kiai Ahmad Fauzan dalam pengembangan dakwah Islam di Jepara. Dalam periode selanjutnya, ia lebih banyak menghabiskan waktu untuk kegiatan berdakwah di luar, dengan cara berkelana dari satu desa ke desa yang lain. Ia menyerahkan pengelolaan madrasah kepada para guru yang lebih muda. Meskipun demikian, sesekali Fauzan tetap memantau proses belajar mengajar di madrasah tersebut.

Metode dakwah dengan cara berkelana menjadikannya dikenal oleh masyarakat luas. Di samping itu, ia juga menyederhanakan ilmu-ilmu agama dengan cara menyajikannya dalam bentuk syair kepada masyarakat. Dari syair-syair yang ditulis dan disampaikan kepada masyarakat tampak bahwa Kiai Ahmad Fauzan adalah tipikal ulama substansial yang lebih mengedepankan pada isi daripada kemasan.

Pemikiran Fauzan yang tergambar dalam syair-syair yang ditulis menunjukkan kemahiran dalam berdakwah. Kemampuan menerjemahkan suatu nilai-nilai agama menjadi syair-syair adalah salah satu ciri khas yang dimilikinya. Di samping dengan metode ceramah atau bandhongan, masyarakat awam juga dapat belajar agama dengan melantunkan syair-syair yang diciptakan Fauzan. Terdapat beberapa syair yang terdokumentasikan dengan baik, antara lain: Syair Asmaul Husna, Syair Isra' Mikraj, Syair pribadi Nabi Muhammad Saw, Syair Pitutur, Syair Kemanusiaan, Syair Kenabian, dan Syair Akhlak Mulia. Di samping syair berbahasa daerah, Fauzan juga menulis sebuah syair berbahasa Arab, yaitu Alfiyah al-Ghazaliyah. Syair tersebut berisi butir-butir nasihat yang disarikan dari karya monumental Imam Ghazali, yaitu Ihya Ulumuddin.

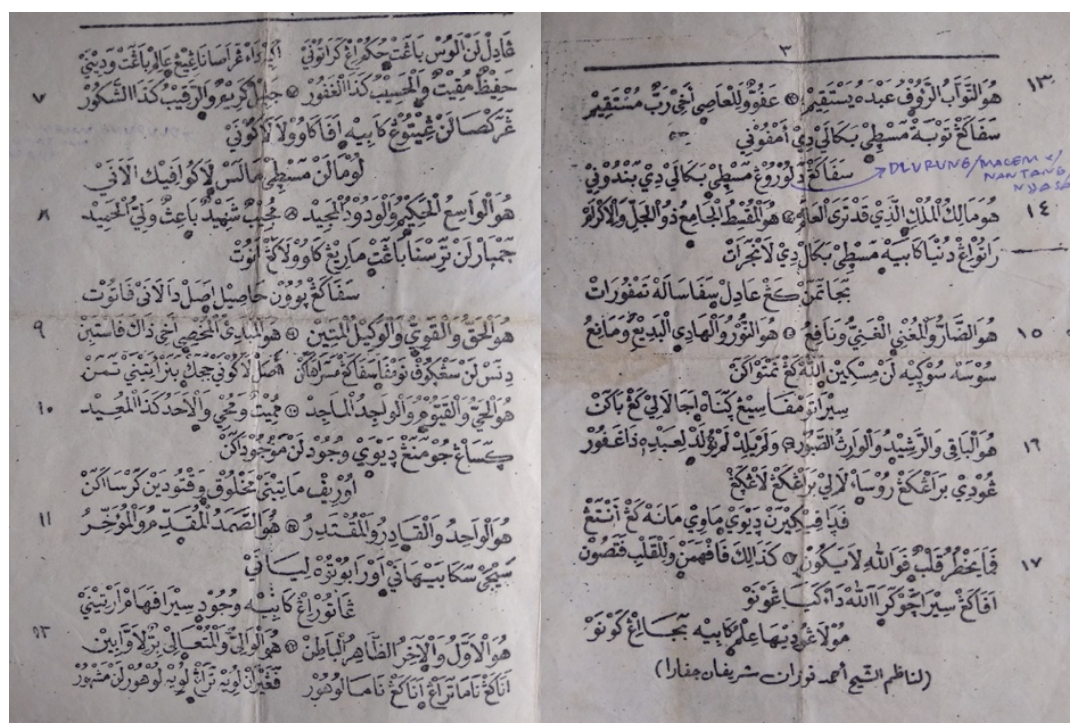

Gambar 1. Naskah asli Syair Asmaul Husna menggunakan huruf pegon Sumber: Dokumentasi Keluarga.

Suatu yang menarik dari sekian banyak syair yang terdokumentasikan, sebagian besar menjelaskan posisi manusia baik sebagai hamba Allah, warga negara, maupun masyarakat. Ketiganya dijelaskan secara bersama-sama dan tidak saling bertentangan. Kiai Ahmad Fauzan menghendaki agar masyarakat dapat menjalankan syariat agama, bermasyarakat dengan baik, dan menjadi pemimpin dengan baik. Misalnya di dalam Syair Asmaul Husna yang di dalamnya tidak hanya menjelaskan tentang tauhid atau 
keimanan semata, tetapi juga menjelaskan etika hidup bersama dengan sesama. Dapat dipahami bahwa Kiai Ahmad Fauzan adalah ulama yang substansial, yang tidak menjadikan agama Islam sebagai kekuatan politik yang bersifat formal. Yang menjadi prinsip adalah ajaran agama Islam dapat terjamin di dalam sebuah negara. Pada saat itu pula, Islam mampu mewarnai kehidupan berbangsa dan bernegara.

\section{Jaringan Politik Kiai Ahmad Fauzan}

Nama Kiai Ahmad Fauzan semakin banyak diperbincangkan ketika tentara Jepang tiba di Jepara pada 1942. Sebagai Ulama, ia mendapatkan perhatian khusus dari pemerintah militer Jepang. Ia bahkan sempat ditangkap oleh polisi militer Jepang (kenpeitai) dan dimasukkan ke dalam penjara karena dituduh sebagai provokator kerusuhan. Akan tetapi, tuduhan tersebut tidak terbukti dan Kiai Ahmad Fauzan pun dibebaskan?

Peranan sebagai pemimpin umat terus berlanjut. Sekitar Agustus 1945, pada masa kemerdekaan Indonesia, para ulama di wilayah Keresidenan Pati berkumpul dan bermusyawarah untuk menghadapi kekuatan tentara Jepang yang masih eksis berkuasa. Di dalam musyawarah tersebut, secara aklamasi para ulama menyepakati Kiai Ahmad Fauzan sebagai ulama muda untuk

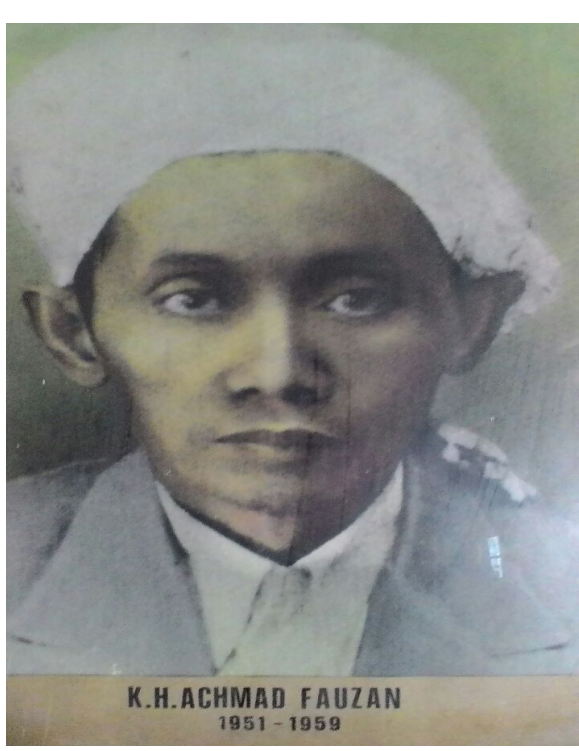

Gambar 2. Foto Kiai Ahmad

Fauzan saat menjabat Sumber: Dok. Kemenag, 1994. memimpin pelucutan senjata tentara Jepang. Dengan kerja sama semua elemen masyarakat, serta dukungan penuh dari para ulama yang menggerakkan para santri, akhirnya pasukan Jepang menyerah kepada massa rakyat di Pati.

Momentum proklamasi kemerdekaan juga menjadi jalan bagi Kiai Ahmad Fauzan untuk aktif pada gerakan-gerakan sosial-keagamaan. NU menjadi organisasi yang dipimpinnya sejak 1945. Sebelumnya, dia juga aktif di Majelis Syuro Muslimin Indonesia (Masyumi) sebagai wakil dari organisasi NU. Sekitar 1949, Kiai Ahmad Fauzan juga dipercaya oleh pemerintah untuk menjadi kepala Kementerian Agama (Kemenag) Kabupaten Jepara. Jabatan ini diemban sampai akhir 1960-an akhir. Penunjukan tersebut tidak lepas dari keaktifannya dalam kegiatan sosial-keagamaan di tengah masyarakat, yaitu dakwah dengan cara berkelana dari satu desa ke desa yang lain. Cara itu telah menjadikan Fauzan lebih mengenal dan dikenal masyarakat luas serta mengetahui kondisi yang terjadi di masyarakat bawah. Pengalamanpengalaman yang ia dapatkan secara langsung dari bawah juga turut mewarnai pemikiran dan metode dakwah yang digunakan. Salah satu metode yang digunakan

${ }^{7}$ Catatan "Riwayat Hidup al-Maghfurlah Kiai Ahmad Fauzan" dalam peringatan Haul ke-22 bulan September tahun 1994 (sumber tidak diterbitkan). 
adalah dengan model penyampaian nilai-nilai agama melalui syair-syair yang relatif mudah dipahami masyarakat.

Ketika NU menjadi partai politik pada 1952, Kiai Ahmad Fauzan tampil sebagai pemimpin (suriyah) partai. Benih-benih perpecahan antara NU dan Masyumi sudah tampak dalam Kongres Masyumi keempat di Yogyakarta pada Desember 1949. Pengaruh kelompok Natsir yang semakin kuat menghasilkan keputusan-keputusan partai yang memojokkan peran ulama tradisional yang ada di NU. Sementara itu, Majelis Syuro (Dewan Penasihat) yang diduduki para ulama NU dibatasi peranan politiknya. Majelis Syuro bukan penentu atas kebijakan partai, tetapi hanya memberikan pendapat dan fatwa apabila dianggap perlu. Ketidakseimbangan antara kelompok modernis dan tradisionalis juga tampak terutama dalam distribusi dalam kursi kabinet pemerintahan (Fealy, 2010: 100-101).

Kiai Ahmad Fauzan turut mendukung keputusan pemisahan NU terhadap Masyumi. Langkah tersebut mudah dipahami mengingat sejak awal perjuangannya, ia berkiprah dalam organisasi NU Jepara. Ketika menjadi bagian dari Majelis Islam A'la Indonesia (MIAI) pada masa Hindia Belanda, serta Masyumi pada masa Jepang dan masa kemerdekaan, Ahmad Fauzan menjadi wakil dari NU atau ulama tradisional di dalam kedua organisasi federasi tersebut.

Kiai Ahmad Fauzan juga merupakan salah seorang ulama generasi pertama yang memelopori berdirinya NU di Jepara. Meskipun tidak ditemukan bukti tertulis terkait kapan NU Jepara sebagai sebuah organisasi terbentuk, bukan berarti paham Ahlussunah wal Jamaah (Aswaja) sebagaimana yang dikembangkan NU tidak berkembang. Sebelum organisasi NU lahir pada 1926 di Surabaya, praktik keberagamaan paham Aswaja sudah menjadi bagian dari kehidupan masyarakat muslim di Jepara. Fakta tersebut dibuktikan dengan kehadiran ulama-ulama beraliran Aswaja di Jepara seperti Kiai Umar al-Samarani, Kiai Sanwasi, K.H. Hasbullah pengasuh Pesantren Balekambang, sekaligus salah seorang guru Kiai Ahmad Fauzan.

Kepemimpinan Fauzan di Partai NU Cabang Jepara sebagai pimpinan tertinggi (rais suriyah) 1952 merupakan posisi penting sebagai penentu arah gerak partai. Suriyah di dalam NU baik sebagai organisasi sosial-keagamaan maupun sebagai partai politik memiliki peranan yang penting dan strategis. Artinya, baik kebijakan maupun program-program partai terutama dalam Pemilu 1955 harus mendapatkan pertimbangan dan restu dari suriyah.

Barangkali ada pola-pola kampanye Partai NU Cabang Jepara yang tidak provokatif dan relatif tenang yang membedakannya dengan daerah lain. Kampanyekampanye yang dilakukan Partai NU tidak begitu keras dengan hujatan dan cacian atau makian.

Dapat digambarkan bahwa suasana kampanye di Jepara sepanjang 1955 relatif tenang, meskipun perselisihan di level bawah yang mewakili dari unsur NU dan Muhammadiyah di Masyumi Jepara sering kali terjadi. Permasalahan yang muncul terutama terkait dengan keagamaan yang bersifat cabang (furu), bukan pokok (ushul). Ungkapan bahwa Muhammadiyah itu tidak berpaham Aswaja sering kali terlontar di tingkat bawah (grassroot). Alasannya karena mereka tidak menggunakan mazhab, 
tetapi secara langsung menggunakan Al-Qur'an dan Hadis. Akan tetapi, ketegangan itu tidak sampai memunculkan pertikaian atau kerusuhan.

Kiai Ahmad Fauzan dengan jaringan politik yang luas, sekurang-kurangnya dengan massa di pedesaan, telah memberikan dampak yang signifikan kepada partai. Perjalanan sebagai seorang kiai keliling dari satu desa ke desa secara konsisten menjadikan banyak murid atau pengikutnya mengikuti pilihan politiknya. Tampaknya motif politik bukanlah tujuan utama kegiatan dakwah yang dilakukan Fauzan sejak 1930-an. Kegiatan politik lebih dimaknai sebagai sebuah sarana untuk berdakwah.

Sikap Kiai Ahmad Fauzan yang santun baik kepada kawan maupun lawan, tanpa menafikan komponen Partai NU yang lain, adalah tiga dari sekian banyak faktor yang menjadikan NU Cabang Jepara berhasil dalam agenda politiknya. Kemenangan Partai NU di Jepara pada Pemilu 1955, serta kondisi daerah yang relatif terjaga tidak dapat dilepaskan dari kontribusi Kiai Ahmad Fauzan sebagai pimpinan partai. Dari 537 tempat pemungutan suara (TPS) yang tersebar di wilayah Jepara, Partai NU menang di sebagian besar TPS untuk Dewan Perwakilan Rakyat Daerah (Suara Merdeka, 1 Oktober 1955).

Pada Pemilu DPRD tahap pertama 29 September 1955, terlihat Partai NU di Jepara unggul dan memenangkan kontestasi pemilihan anggota di parlemen. Kemenangan Partai NU di Jepara jauh lebih unggul di antara tiga partai yang lain, yaitu: PNI, PKI, dan Masyumi. Para calon legislatif dari Partai NU Jepara tersebar merata di wilayah Jepara. Mereka adalah para pengurus NU di tingkat kecamatan atau Majelis Wakil Cabang (MWC) yang memenuhi persyaratan untuk menjadi wakil rakyat. Komposisinya didasarkan atas jumlah penduduk di daerah pemilihan (Wawancara dengan K.H. Mubin, 17 April 2018). Pada Pemilu selanjutnya, yaitu 15 Desember 1955 untuk memilih anggota Dewan Konstituante, NU Jepara kembali mengukir kemenangan mutlak di atas tiga partai besar lainnya. Berikut adalah tabel hasil perolehan suara Partai NU dengan tiga partai besar yang lain di Kabupaten Jepara pada Pemilu 1955.

\begin{tabular}{ccc}
\multicolumn{3}{c}{ Tabel 1. Perolehan Suara Empat Partai Besar di Kabupaten Jepara } \\
\hline Partai Politik & Perolehan suara DPR & $\begin{array}{l}\text { Perolehan suara Dewan } \\
\text { Konstituante }\end{array}$ \\
\hline NU & 110.953 & 105.221 \\
PNI & 45.999 & 53.043 \\
PKI & 19.377 & 21.705 \\
Masyumi & 10.953 & 10.991 \\
\hline
\end{tabular}

Sumber: Suara Merdeka, 19 Desember 1955.

Kemenangan Partai NU di Jepara pada Pemilu 1955 tidak dapat dipisahkan dari kiprah Ahmad Fauzan. Pertama, kegiatan dakwah dan organisasi yang dilakukan sejak zaman Jepang sampai era kemerdekaan di pedesaan Jepara memiliki kontribusi yang besar dalam mendulang suara partai. Kemudian di tahun 1950-an, sebagian kegiatan 
keagamaan itu terlembagakan di dalam organisasi NU. Pada saat itu wadah organisasi menjadi semacam pengikat bagi para jamaah.

Keadaan tersebut juga didukung dengan faktor kedua, yaitu kondisi sosialmasyarakat Jepara yang memiliki ikatan yang kuat terhadap ulama. Kharisma dari Ahmad Fauzan menjadi patron bagi masyarakat, baik dalam mengikuti anjuran, fatwa, maupun pilihan politik. Hubungan mutualisme ini tidak terjadi dalam waktu yang pendek, tetapi dalam jangka waktu yang relatif lama.

Ketiga, strategi kampanye yang santun dengan tidak bersikap kaku dan ditambah menggunakan pendekatan nilai-nilai agama. Dengan gaya orasinya yang khas, yaitu membawakan syair-syair yang mencerminkan suasana zaman menjadikan konstituen ideologis turut serta dalam gerbong politik Kiai Ahmad Fauzan. Keempat, kesuksesan Partai NU di Jepara juga ditopang bangunan partai yang mulai mapan dengan berdirinya badan otonom (Banom) yang banyak didirikan pada 1950-an, seperti Ansor-Banser, Fatayat, dan Muslimat. Beberapa Banom NU tersebut turut memainkan peranan penting khususnya di tingkat pedesaan.

Atas kemenangan mutlak Partai NU di Jepara, sebagai pimpinan partai, Fauzan memiliki kesempatan untuk menjadi bupati Jepara. Banyak kalangan yang menilai Fauzan akan mengambil kesempatan tersebut. Akan tetapi, dugaan tersebut salah. Pilihan yang diambil adalah dengan memberikan kepada kader NU yang lain. Jabatan tersebut dipercayakan kepada Sahlan. Posisinya sebagai panutan masyarakat menjadikan faktor penting atas kemenangan Partai NU di Jepara. Di samping itu, banyaknya masyarakat yang mengenal Fauzan melalui pengajian dan kampanyekampanye yang dilakukan cenderung bersikap santun menjadi faktor yang lain. Tidak sulit bagi Kiai Ahmad Fauzan untuk mendapatkan dukungan politik dari masyarakat luas.

Syair-syair yang disampaikan kepada masyarakat luas lebih bersifat pengingat dan penyadaran atas penyemaian nilai-nilai keagamaan dan kebangsaan. Manuver politik yang dilakukan Fauzan bukanlah untuk tujuan kekuasaan, tetapi diorientasikan untuk kebaikan (kemaslahatan) masyarakat, bangsa, dan negara.

Perjalanan dakwah di masyarakat membawa keberhasilan partai dalam memenangi suara NU di Jepara pada Pemilu 1955. Setelah itu, dalam periode selanjutnya, Fauzan tidak lagi aktif dalam kegiatan politik praktis. Fauzan lebih memilih membina umat di Jepara melalui Kemenag Kabupaten Jepara. Komitmen dalam memegang prinsip agama dibuktikan oleh Fauzan dengan memberikan syarat kepada pimpinan Kantor Urusan Agama (KUA) di setiap kecamatan yang ada di Jepara harus dapat membaca kitab para ulama salaf atau yang lazim disebut Kitab Kuning. Hampir dapat dipastikan bahwa orang-orang yang dapat membaca karyakarya ulama salaf adalah mereka yang lulus dari pesantren atau orang-orang yang menempuh pendidikan tradisional yang dikembangkan para ulama-ulama salaf.

Keilmuan yang dimiliki dan disertai dengan perilaku (akhlak) yang baik menjadikannya sebagai seorang ulama sufi yang disegani masyarakat. Berbagai pemikirannya, baik di bidang keagamaan (akidah, syariat, dan tasawuf) maupun 
kebangsaan terlihat dari syair-syair yang disampaikan kepada masyarakat, terutama pascakemerdekaan.

Kegiatan berdakwah Fauzan masih terus berlanjut meski ia tidak lagi memiliki jabatan baik politik maupun pemerintahan. Metode dakwah yang khas, yakni berkelana dan menggunakan syair-syair keagamaan dan kebangsaan masih dilakukan pada 1960-an. Perjalanan intelektualnya dengan ulama-ulama di Makkah dan pengalaman belajar dari beberapa pesantren di Jawa Tengah mendorong untuk menetapkan diri membangun kekuatan Islam di kawasan pedesaan Jepara berbasis masyarakat tradisional. Nilai-nilai etis yang diajarkan Fauzan baik melalui syair, karya tulis maupun keteladanan kepada masyarakat masih dapat dirasakan melalui putra-putrinya.

\section{Simpulan}

Bagi masyarakat Jepara, figur Kiai Ahmad Fauzan berperan dalam pendidikan terlihat sejak selesainya pendidikan di pesantren dengan mendirikan sebuah madrasah di daerah Bangsri pada 1930-an awal. Di lembaga pendidikan tersebut Fauzan memulai merintis peran-peran sebagai kiai. Ketika tentara Jepang tiba di Jepara pada 1942, Fauzan mendapatkan perhatian khusus dari pemerintah militer Jepang. Dengan posisinya sebagai ulama, ia sempat ditangkap oleh polisi militer Jepang (kenpeitai) dan dimasukkan ke dalam penjara atas tuduhan sebagai provokator kerusuhan (baca: krayahan). Akan tetapi, tuduhan tersebut tidak terbukti dan Fauzan pun dibebaskan.

Proses keulamaan Kiai Ahmad Fauzan melalui lembaga pendidikan maupun berdawah keliling terus dilakukan hingga kemerdekaan. Melalui NU, Kiai Ahmad Fauzan berjuang untuk menegakkan paham Aswaja. Paham yang dikembangkan tersebut tampak dalam syair-syair yang disampaikan kepada masyarakat. Syairsyairnya sebagai salah satu ekspresi pemikiran, yang dibawa hampir sebagian besar tidak memisahkan kedudukan manusia sebagai hamba dan masyarakat bangsa.

Pemikiran Fauzan yang tergambar dalam syair-syair yang ditulis menunjukkan kemahiran dalam berdakwah. Kemampuan menerjemahkan suatu nilai-nilai agama menjadi syair-syair adalah salah satu ciri khas yang dimilikinya. Di samping dengan metode ceramah atau bandhongan, masyarakat awam juga dapat belajar agama dengan melantunkan syair-syair yang diciptakan Fauzan. Terdapat beberapa syair yang terdokumentasikan dengan baik, antara lain: Syair Asmaul Husna, Syair Isra Mikraj, Syair pribadi Nabi Muhammad Saw, Syair Pitutur, Syair Kemanusiaan, Syair Kenabian, dan Syair Akhlak Mulia. Di samping syair berbahasa daerah, Fauzan juga menulis sebuah syair berbahasa Arab, yaitu Alfiyah al-Ghazaliyah. Syair tersebut berisi butir-butir nasihat yang disarikan dari karya monumental Imam Ghazali, Ihya Ulumuddin. Di dalam syair-syair yang ditulis dan disampaikan oleh Fauzan, terdapat tiga kategori pemikiran, yaitu akidah, syariat, tasawuf, dan kebangsaan.

Syair juga menjadi metode dalam kampanye saat Pemilu 1955. NU yang pada waktu itu menjadi partai politik memenangi pemilihan secara mutlak di Jepara. Hal tersebut tidak dapat dipisahkan dari peranan Kiai Ahmad Fauzan sebagai pimpinan 
partai (suriyah). Di samping itu, pengalaman hidup bersama dengan masyarakat dalam jangka waktu yang relatif lama menjadi alasan tersendiri.

Kegiatan berdakwah Fauzan masih terus berlanjut meski ia tidak lagi memiliki jabatan baik di politik maupun pemerintahan. Metode dakwah yang khas, yakni berkelana dan menggunakan syair-syair keagamaan dan kebangsaan masih dilakukan di tahun 1960-an. Perjalanan intelektual Fauzan dengan ulama-ulama di Makkah dan pengalaman belajar dari beberapa pesantren di Jawa Tengah mendorongnya untuk menetapkan diri membangun kekuatan Islam di kawasan pedesaan Jepara berbasis masyarakat tradisional. Nilai-nilai etis yang diajarkan Fauzan baik melalui syair, karya tulis maupun keteladanan kepada masyarakat masih dapat dirasakan melalui putra-putrinya. Fauzan wafat pada 12 Maret 1972 di Bangsri, Jepara. Sebagai bentuk penghorrmatan, nama Fauzan pun diabadikan menjadi salah satu nama jalan di Kabupaten Jepara.

\section{Referensi}

Azra, Azyumardi (1989). Konteks berteologi masyarakat Indonesia. Jakarta: Wacana Ilmu. Fealy, Greg (2003). Ijtihad politik ulama: Sejarah NU 1952-1967, terjemahan Farid Wajdi dan Mulni Adelina Bachtar. Yogyakarta: LKis.

Florida, N. (2003). Menyurat yang silam, menggurat yang menjelang: Sejarah sebagai nubuat di Jawa masa kolonial. Yogyakarta: Bentang Budaya.

Hady, Nurrudin (2010). Teori konstitusi negara demokrasi: Pemahaman konstitusionalisme demokrasi pasca amandemen UUD 1945. Malang: Setara Press.

Kartodirdjo, Sartono (1993). Pendekatan ilmu sosial dalam metodologi sejarah. Jakarta: Gramedia Pustaka Utama.

Kuntowijoyo (1991). Paradigma Islam: Interpretasi untuk aksi. Bandung: Mizan.

Santoso, L. (2014). Sejarah terlengkap gerakan separatis Islam. Yogyakarta: Palapa.

Sianipar (2002). Runtuhnya negara bangsa. Jakarta: Lemhanas Republik Indonesia.

Siraj, Said Agil (2015). Islam sumber inspirasi budaya nusantara: Menuju masyarakat mutamaddin. Jakarta: LTN NU.

Siregar, F. M., Setiawan, N. K., Setio, R. (2013). Religious leader and charismatic leadership in Indonesia: The role of kyai in pesantren in Java. Kawistara, 3(2): 117-126.

Steenbrink, Karel A. (1984). Beberapa aspek tentang Islam di Indonesia abad ke-19. Jakarta: PT Bulan Bintang.

Steenbrink, Karel A. (1991). Pesantren, madrasah, sekolah, cetakan kedua. Jakarta: LP3ES. Suara Merdeka, 1 Oktober 1955.

Suara Merdeka, 19 Desember 1955.

Suhartono (1991). Apanage dan bekel: Perubahan sosial di pedesaan Surakarta 1830-1920. Yogyakarta: Tirta Wacana.

Sulistiyono, S. T. (2015). Diaspora maritim dan proses reformasi keindonesiaan. Jakarta: Badan Informasi Geoospasial.

Suryo, Djoko (2009). Transfomasi masyarakat Indonesia dalam historiografi Indonesia modern. Yogyakarta: STPN Press. 
Ulum, A. Arbi, M. Y. (2016). KH. Sholeh Darat: Maha Guru Para Ulama Nusantara 18201903. Depok: Shahifa.

Wahid, M. (peny.) (1999). Geger di "Republik" NU. Jakarta: Lakpesdam NU dan Kompas. 